\title{
Efficacy of Tocilizumab in Patients with a Moderate and Severe COVID-19: A Retrospective Single Center Cohort Study
}

\author{
Orta ve Ağır COVID-19 Hastalarında Tocilizumabın Etkinliği: Retrospektif Tek Merkezli Kohort \\ Çalışması
}

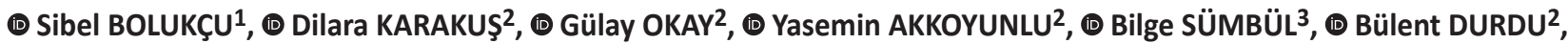 \\ (1) Meliha Meriç KOÇ², (1) Turan ASLAN² \\ 1 Yeditepe University Faculty of Medicine, Department of Infectious Diseases and Clinical Microbiology, istanbul, Turkey \\ ${ }^{2}$ Bezmialem Vakıf University Faculty of Medicine, Department of Infectious Diseases and Clinical Microbiology, Istanbul, Turkey \\ ${ }^{3}$ Bezmialem Vakıf University Faculty of Medicine, Department of Microbiology and Clinical Microbiology, Istanbul, Turkey
}

\section{Abstract}

Introduction: Interleukin-6 (IL-6) is the key cytokine in "cytokine release syndrome" and associated with the lung fibrosis. Tocilizumab (TCZ) reduces the negative effects of inflammation by blocking the binding of IL-6 to its receptor.

Materials and Methods: This was a retrospective observational cohort study. Patients with microbiologically-confirmed Severe acute respiratory syndrome-Coronavirus-2 infection who received TCZ and standard treatment for Coronavirus disease-2019 (COVID-19) were evaluated in the study. Results: A total of 64 severe and moderate COVID-19 cases were included in this study. The mean age of the patients was $57.8 \pm 13.9$ years and $68.8 \%(n=44)$ of them were male, 54.7\% $(n=35)$ of them had a severe COVID-19 infection and 45.3\% ( $n=29)$ of them received TCZ therapy. Standard treatment group and TCZ group were compared in terms of the mortality and clinical changes such as a fever response and need for oxygen support. Fever response was detected within the first day of the treatment in the TCZ group. Additionally, need for oxygen support was lower in the TCZ group, although the difference was not statistically significant. Admission to the intensive care unit and mortality were lower in the TCZ group. Conclusion: Efficacy of TCZ should be assessed in randomized placebo-controlled trials in the early phase of COVID-19 patients. Keywords: Tocilizumab, IL-6, COVID-19, Turkey

Öz

Giriş: Akciğer fibrozisi ve "sitokin salınım sendromu" ile ilişkili anahtar sitokin interlökin-6'dır (IL-6). Tocilizumab (TCZ), IL-6'nın reseptörüne bağlanmasını bloke ederek enflamasyonun olumsuz etkilerini azaltır.

Gereç ve Yöntem: Bu çalışma retrospektif gözlemsel bir kohort çalışmasıydı. Çalışmada mikrobiyolojik olarak doğrulanmış Şiddetli akut solunum yolu sendromu-Koronavirüs-2 enfeksiyonu olan, TCZ ve Koronavirüs hastalığı-2019 (COVID-19) için standart tedavi alan hastalar değerlendirildi.

Bulgular: Çalışmamıza toplam 64 şiddetli ve orta düzeyde COVID-19 olgusu dahil edildi. Hastaların yaş ortalaması 57,8 $\pm 13,9$ yıl olup, \%68,8'i ( $n=44$ ) erkek, \%54,7'si ( $n=35)$ ağır COVID-19 enfeksiyonu geçirdi ve \%45,3'ü ( $n=29)$ TCZ tedavisi aldı. Standart tedavi grubu ile TCZ grubu mortalite ve ateş yanıtı ve oksijen desteği intiyacı gibi klinik değişiklikler açısından karşılaştırıldı. Tocilizumab grubunda tedavinin ilk gününde ateş yanıtı saptandı. Ayrıca, istatistiksel olarak anlamlı olmasa da TCZ grubunda oksijen desteğine intiyaç daha kısa süreliydi. Tocilizumab grubunda yoğun bakıma kabul edilme ve mortalite daha düşüktü.

Sonuç: Erken evre COVID-19 hastalarında TCZ'nin etkinliği randomize plasebo kontrollü çalışmalarda değerlendirilmelidir. Anahtar Kelimeler: Tocilizumab, IL-6, COVID-19, Turkey

Cite this article as: Bolukçu S, Karakuş D, Okay G, Akkoyunlu Y, Sümbül B, Durdu B, Koç MM, Aslan T. Efficacy of Tocilizumab in Patients with a Moderate and Severe COVID-19: A Retrospective Single Center Cohort Study. Mediterr J Infect Microb Antimicrob. 2021;10:68 


\section{Introduction}

The Coronavirus disease-2019 (COVID-19), caused by the Severe acute respiratory syndrome-Coronavirus-2 (SARS-CoV-2), was first established in Wuhan, China, in the late 2019, and was announced as a pandemic by the World Health Organization (WHO) on March 11, 2020. Globally, as of June 29, 2021, there have been 181,007,816 confirmed cases of COVID-19, including $3,927,222$ deaths, reported to WHO. The first case in our country was detected on March 11, 2020. In Turkey, from March 11-June 29, 2021 there have been 5,409,027 confirmed cases of the COVID-19 with 49,576 deaths ${ }^{[1]}$.

Tocilizumab (TCZ) was first approved for use in Castleman's disease in 2015. Thereafter it was indicated in the rheumatoid arthritis, juvenile idiopathic arthritis, polyarticular form of juvenile idiopathic arthritis ${ }^{[2]}$. It was first used in patients with COVID-19 off-label in the observational study by Xu et al. ${ }^{[3]}$ Tocilizumab binds to interleukin-6 (IL-6) receptors with high affinity as a monoclonal antibody to IL-6 receptors and inhibits the deleterious effects of the inflammation by blocking the ligation of the IL-6 to its receptors ${ }^{[4]}$. There are some observational and randomized controlled trials regarding the use of TCZ in patients with COVID-19 ${ }^{[5-8]}$.

In this observational study related to results of off-label use of TCZ in COVID-19, our primary goal was to investigate the effects of the TCZ on mortality and admission to the intensive care unit (ICU) in patients with the moderate and severe COVID-19, and secondary goal was to assess the clinical improvement and length of the hospital stay course with the use of TCZ.

\section{Materials and Methods}

\section{Patients and Study Design}

This was a retrospective observational cohort evaluation conducted at Bezmialem Vakıf University Hospital. Patients with microbiologically confirmed SARS-CoV-2 infection who received TCZ and standard treatment for COVID-19 between March 11 and May 29, 2020 were enrolled in the study. The accepted method for the diagnosis of COVID-19 was a real-time reverse transcriptasepolymerase chain reaction (rRT-PCR) assay positivity of the nasopharyngeal and oropharyngeal samples and/or Abbott SARSCoV-2 IgG assay, which was performed on the Abbott Architect i4000SR (Abbott Diagnostics, Chicago, USA). SARS-CoV-2 by rRTPCR and Abbott SARS-CoV-2 IgG assay were performed in the laboratory of Bezmialem Vakıf University Hospital. The patients with the clinical or radiological findings beside SARS-CoV-2 IgG positivity were included in the study even they were rRT-PCR negative.
Severity of the disease was determined according to the "National Guide for COVID-19" recommended by the Scientific Committee of the Ministry of Health. The study population was grouped according to the severity of COVID-19 pneumonia according to the Turkish Ministry of Health COVID-19 guidelines; subjects with a severe clinical condition with tachypnoea ( $\geq 30 / \mathrm{min})$, oxygen saturation $<90 \%$ breathing at room air, together with a bilateral diffuse pulmonary infiltrates and hospitalized. Favipravir (FVP) was recommended on March 25, 2020, and TCZ was recommended on April 2, 2020 in the national guide off-label. Treatments of the patients in the study were ordered in accordance with these recommendations. The study were approved by the Bezmialem Vakıf University of Clinical Research Ethics Committee (no: 71306642-050.05.04, date: 06.05.2020).

Initial treatment for all our patients in accordance with the recommendations of the Ministry of Health COVID-19 Guidelines included a loading dose of $2 \times 400 \mathrm{mg}$ hydroxychloroquine on the first day followed by the maintenance dose of $2 \times 200 \mathrm{mg}$ for four days as well as $2 \times 75 \mathrm{mg}$ oseltamivir for $5 \pm 1$ days $\times 500$ $\mathrm{mg}$ azithromycin on the first day and $1 \times 250 \mathrm{mg}$ for four days. In addition, depending on the clinical severity and the progression of the disease during the course, FVP was added to initial or maintenance treatment $(2 \times 1600 \mathrm{mg}$ loading on the first day followed by the $2 \times 600 \mathrm{mg}$ maintenance for four days). Despite the standard therapy used, we concluded that patients with a progressive deterioration in the laboratory values (increase in acute phase reactants, development of cytopenia, increase in lactate dehydrogenase, etc.), persistent fever, decreased $\mathrm{SpO}_{2}$ $(<93 \%)$ and deepened respiratory distress progressed to the cytokine storm period and we used TCZ in their treatment. As a suggestion in the guidelines of Turkish Ministry of Health, the first dose of the TCZ was administered as $400 \mathrm{mg}$ intravenously. A second dose of TCZ was administered in case of increased oxygen need and/or intractable fever at the discretion of the treating clinician within the 24 hours. Exclusion criteria for the use of TCZ were an age of $<18$ years, coexistent infections other than COVID-19, lower than 500 per $\mu \mathrm{L}$ neutrophils or lower than $50 \times 10^{9}$ platelets, active diverticulitis, inflammatory bowel disease, or another symptomatic gastrointestinal tract condition that may predispose the patients to bowel perforation and acute hepatitis.

\section{Statistical Analysis}

Statistical analyses were performed using a Statistical Package for the Social Sciences (SPSS), version 16.0 (SPSS Inc., Chicago, IL, USA) and the Prism version 8.43 (GraphPad Software, CA, USA). Descriptive statistics were provided for all the variables and presented as mean \pm standard deviation and median (interquartile range) for continuous variables and as number and percentage for the categorical variables. Statistical tests 
of significance (Student's t-test and Mann-Whitney U test for continuous variables and the $\chi^{2}$ test or Fischer's exact test for categorical variables) were conducted to assess the differences between the cohorts (TCZ vs. standard treatment groups). Corresponding lymphocyte counts and ferritin levels in TCZ and standard treatment groups on the index day, $3^{\text {rd }}, 5^{\text {th }}$, and $7^{\text {th }}$ days of the hospitalization and on $2^{\text {nd }}$ and $4^{\text {th }}$ days after the treatment were compared by using Friedman and MannWhitney $\mathrm{U}$ test. The Cox proportional-hazards regression model was applied to determine the potential risk factors associated with the mortality. A final model selection was performed via a Backward Stepwise (Likelihood-ratio) selection. A statistical test was considered significant at $p \leq 0.05$ and a $95 \%$ confidence interval (CI).

\section{Results}

A total of 64 individuals were enrolled in the study with a male ratio of $68.8 \%(n=44)$. The mean age was $57.8 \pm 13.9$ years. $0 n$ admission, $54.7 \%(n=35)$ of the patients had a severe COVID-19 infection and $45.3 \%(n=29)$ of the patients received TCZ. During the treatment of the individuals, 18.7\% ( $n=12)$ were admitted to the ICU and $9.3 \%(n=4)$ died.

Comparisons between the standard treatment group and TCZ group were demonstrated in the Table 1. Demographic data, comorbidities, and initial laboratory findings were comparable between the groups. Elapsed time for fever response was significantly lower in the TCZ group $(p=0.0001)$. The median day was on the $7^{\text {th }}$ day, on which TCZ was ordered after the hospitalization. Regarding the need for oxygen after the treatment, admission rate to $\mathrm{ICU}$, and overall mortality were in TCZ group, the differences were not statistically significant ( $p=0.32, p=0.355, p=0.209$, respectively).

Increase in the lymphocyte count on the $4^{\text {th }}$ day after the treatment was significantly higher $(p=0.002)$. However, a substantial increase in the lymphocyte count did not occur in standard treatment group $(p=0.064)$. Median lymphocyte counts on the $4^{\text {th }}$ day after the treatment were comparable between groups ( $p=0.474)$. Median ferritin levels were decreased in both groups after the treatment (standard group $p=0.017$, TCZ group $p=0.0001$ ). Median ferritin levels on the $4^{\text {th }}$ day of the treatment were not different ( $p=0.281$ ) (Figure 1$)$. In summary, increase in the lymphocyte counts and decrease in the ferritin levels after the treatment in both groups were comparable but on the $4^{\text {th }}$ day lymphocyte count increase was significant in the TCZ group.

Table 2 demonstrates the increase in the mortality parallel to the increase in Charlson comorbidity index in Cox regression model (Hazard ratio: 2.75, Cl: 95\%: 1.28-5.93; $p=0.009$ ). In univariate analyses, median Charlson comorbidity indices of the mortality group and the survival group were five and one, respectively $(p=0.003)$.

\section{Discussion}

In this study, we investigated the treatments of 64 patients having moderate and severe COVID-19, retrospectively. The groups were comparable in terms of the demographic data, comorbidities, initiation and clinical presentation of the disease,

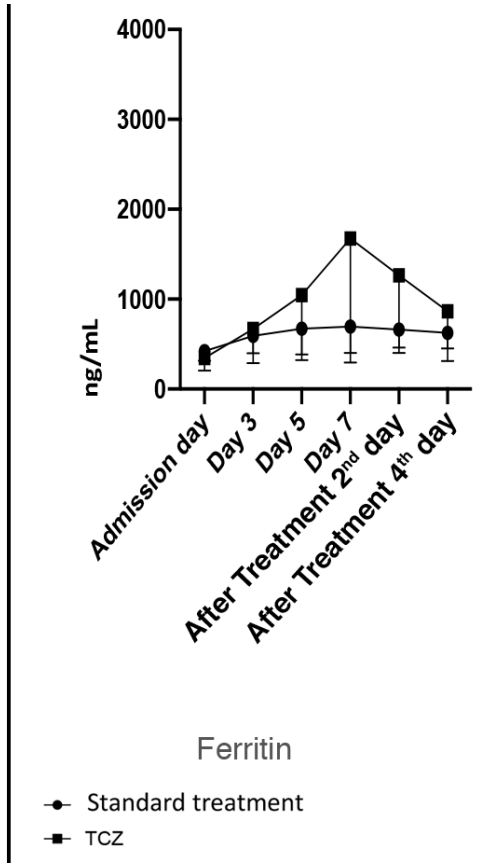

Figure 1. Lymphocyte counts and ferritin levels of groups during admission and during follow-up

TCZ: Tocilizumab 
Table 1. Comparison of the standard treatment and TCZ group

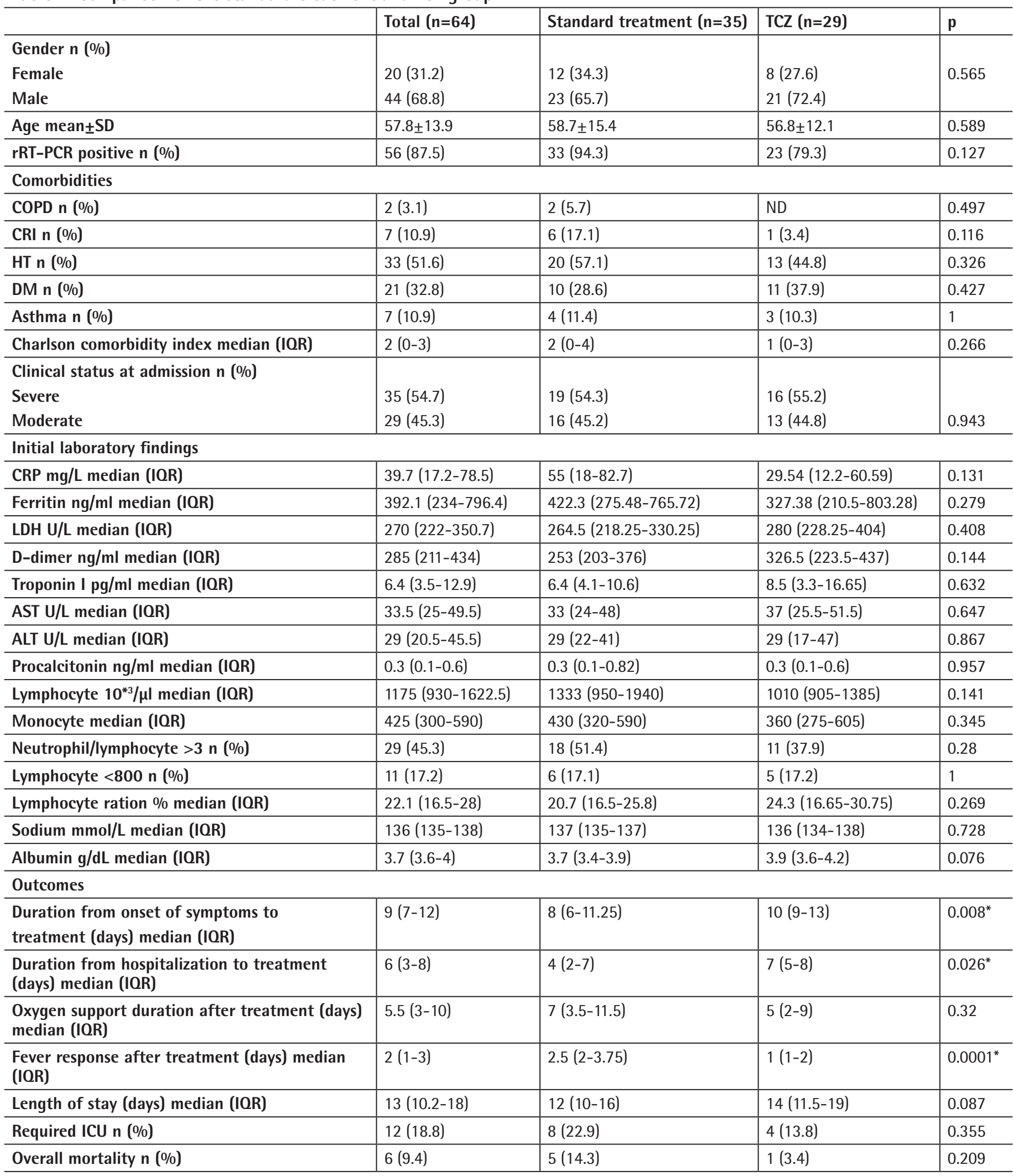

TCZ: Tocilizumab, rRT-PCR: Reverse transcriptase-polymerase chain reaction, COPD: Chronic obstructive pulmonary disease, CRI: Chronic renal injury, HT: Hypertension, DM: Diabetes mellitus, IQR: Interquartile range, CRP: C-reactive protein, ICU: Intensive care unit, SD: Standard deviation, AST: Aspartate aminotransferase, ALT: Alanine aminotransferase, LDH: Lactate dehydrogenase 
and initial laboratory findings. Fever response time after the treatment in TCZ group was significantly shorter. In addition, need for the oxygen support, admission to ICU, and mortality was lower in the TCZ group.

In the retrospective study of Xu et al. ${ }^{[3]}$ including 21 severe and critical COVID-19 cases in the early period of the pandemic; regression in fever on the first day of the treatment, decreased need for the oxygen support, and improvement in the CT findings were shown with TCZ treatment suggesting that TCZ could be an effective therapeutic for COVID-19. Also in our study, fever response was positive on the first day of the TCZ treatment, need for the oxygen support decreased, admission rate to the ICU and mortality were lower in the TCZ group. In a prospective, multicenter, single-arm pilot study of the Sciascia et al. ${ }^{[4]}$, mortality after the TCZ was $11 \%$ and likelyhood of sixday survival after the TCZ was 2.2-fold higher in the multivariate analyses. Decrease in the inflammatory markers, fever response, and improvement in the ventilation parameters after the first dose of TCZ were reported on the same study. In both studies, results for TCZ treatment were assessed, but the authors did not compare the results with a control group.

Tomasiewicz et al ${ }^{[9]}$ reported a brisk decrease in a need for oxygen support in most of the patients following the first TCZ dose, and an inverse relationship between the comorbidities and the clinical improvement in their study of 28 severe COVID-19 patients. Thus, they noted more rapid improvement in those without comorbidities. They observed decreases in C-reactive protein (CRP), procalcitonin, and fibrinogen levels and an increase in the lymphocyte count after the TCZ treatment. However, Keske et al. ${ }^{[6]}$ did not report an increase in the lymphocyte count after the TCZ treatment. We observed an increase in the lymphocyte count in our moderate and severe COVID-19 patients in this study, but we are not able to comment on critical COVID-19 patients because they were excluded from the study.

Rojas-Marte et al. ${ }^{[7]}$ reported a decreased mortality in nonintubated patients in TCZ group in their retrospective casecontrol study including 193 severe to critical COVID-19 patients. They also reported a decreased mortality in the overall TCZ group, but the difference was not statistically significant. Klopfenstein et al. ${ }^{[10]}$ demonstrated a lower ICU admission rate in the TCZ group compared with a standard treatment group, despite the higher Charlson comorbidity index, median CRP levels, and need for oxygen support and lower lymphocyte rate of the former group, in their casecontrol study from French. Mortality did not differ in the TCZ and standard treatment groups ( $n=5, n=12$, respectively). In addition, in this study, invasive mechanical ventilation (IMV) was needed in eight patients in a standard treatment group, while none of the patients were mechanically ventilated in the TCZ group. The authors hypothesized that the TCZ treatment could be effective even in the presence of the known risk factors for mortality. Luo et al. ${ }^{[11]}$ also proposed that the TCZ treatment may be more beneficial in non-severe forms of the disease as Rajes-Marte et al. ${ }^{[7]}$. Keske et al. ${ }^{[6]}$ reported that they did not use TCZ in the early period of the pandemic due to the inadequate data about safety and efficacy of the drug except mechanically ventilated patients in the ICU, but afterwards with the administering the drug in the early phases of the disease in hospitalized patients in the wards they observed a decrease in the ICU admission ratio and mortality. In our study including patients with a moderate and severe clinical presentation, mean ages, Charlson comorbidity indices, initial clinical presentations of the patients (moderate/severe), and initial laboratory findings were similar between the standard and TCZ treatment groups; although ICU admission rate and mortality were lower in the TCZ group.

Toniati et al. ${ }^{[12]}$ used their own Brescia COVID-19 Respiratory Severity Scale (BCRSS) scoring system for assessing the severity of the disease in their single-center study of 100 patients in Brescia in Italy. The higher the score is, the more severe the disease was. Of the patients, $57 \%$ had a BCRSS score $<3$. The authors observed clinical and respiratory improvement in the $58 \%$ of patients in 24-72 hours after the TCZ treatment. In this study, $65 \%$ percent of the patients in the wards and $74 \%$ of the patients in ICU were cured.

In the study by Knorr et al. ${ }^{[13]}$, clinical improvement was noted in only $15 \%$ of the patients on the $7^{\text {th }}$ day of the TCZ treatment and in $29 \%$ of the patients on the $14^{\text {th }}$ day. Of the included patients, $42 \%$ died. The authors postulated the high percentage of the patients on IMV before the TCZ treatment, and presence

Table 2. Univariate and multivariate analyses of the risk factors for mortality

\begin{tabular}{|c|c|c|c|}
\hline & Median (IQR) & OR (Cl: 95\%) & HR (Cl: 95\%) \\
\hline Charlson comorbidity index & $5^{*}(2.75-6.75)$ & & $2.75^{*}(1.28-5.93)$ \\
\hline Lymphocyte ratio \% & $20.4(10.3-27.9)$ & & $0.99(0.86-1.14)$ \\
\hline Age $>60$ years $n(\%)$ & & $8.8(0.96-80.5)$ & $1.23(0.09-15.8)$ \\
\hline CRP mg/dl & $56.2(14.5-107.4)$ & & $0.99(0.96-1.01)$ \\
\hline Tocilizumab received $\mathrm{n}(\%)$ & & $0.2(0.02-1.94)$ & $0.19(0.009-4.24)$ \\
\hline
\end{tabular}

OR: Odds ratio, HR: Hazard ratio, IQR: Interquartile range, Cl: Confidence interval 
of the known risk factors for mortality such as diabetes and/or hypertension for the lower cure rate and a higher mortality. In TESEO cohort real-world data, TCZ treatment reduced the need for IMV and mortality more than the standard therapy $\operatorname{did}^{[14]}$.

In stop-COVID-19 multicenter study, in which the data were retrospectively registered, and the patients were received standard treatment or TCZ on the first $48^{\text {th }}$ hours after an admission to the ICU, mortality was lower in the TCZ group. In the standard treatment group, patients were likely to be older ( $51 \%$ were $\geq 60$ years of age), have a $\mathrm{PaO}_{2} / \mathrm{FiO}_{2}$ ratio $<200$ in admission to the ICU (50.2\%), and be receiving steroids (52.3\%). This could explain the relatively high risk for mortality in the control group ${ }^{[15]}$.

In a study from seven centers from Boston including patients in the early phase of the disease, TCZ treatment was shown to be ineffective in reducing IMV need and mortality. The authors noted that the patients' $\geq 65$ years of age were more common in the TCZ group than the placebo group despite the randomization $^{[16]}$. It is known that older age is a risk factor for poor prognosis. Therefore, TCZ treatment group may have worse results.

In Empacta study, the authors demonstrated that in the patients with moderate or severe COVID-19, in the presence of hypoxemia which does not need MV, TCZ treatment could be more effective than the standard treatment in terms of clinical improvement, but not in reducing mortality ${ }^{[17]}$.

In RCT-TCZ-COVID-19 randomized controlled clinical trial, standard treatment and the TCZ treatment groups were compared regarding decreasing the clinical worsening and ICU admission ratio in patients in whom the treatment was started in the early periods of the disease. Those who need oxygen support, had fever $>38^{\circ} \mathrm{C}$ at least for two days, and/or had the increasing acute phase reactant levels were included. Exclusion criteria were having need for IMV or NIMV, having the multiple comorbidities, advanced age, having a risk for admission to the ICU. Despite the randomization, at the beginning, CRP, IL-6, ferritin, and D-dimer levels were lower and anti-viral therapy use were more frequent in the control group than in the TCZ group. In conclusion, TCZ group was not superior to a standard treatment group in terms of the clinical worsening, admission to the ICU ratio, mortality, and discharge from the hospital[ ${ }^{[18]}$.

CORUMINO-19 Collaborative Group compared the standard treatment group with the TCZ group in their randomized controlled open-label study including the patients with a moderate and severe COVID-19 and reported decreased need for MV or NIMV or decreased mortality in those who had a CRP level $>15 \mathrm{mg} / \mathrm{dl}$ on the $14^{\text {th }}$ day of the treatment in the TCZ group. However, mortality rates did not differ on the $28^{\text {th }}$ day of the treatment but on the $90^{\text {th }}$ day, mortality was lower in the TCZ group ${ }^{[19]}$.

In the RECOVERY study including a large patient group who suffered from a hypoxia and had CRP levels $\geq 75 \mathrm{mg} / \mathrm{dl}$, the authors assessed the efficacy of the TCZ treatment. They demonstrated that TCZ treatment reduced the need for IMV, the mortality on the $28^{\text {th }}$ day, and increased the discharge rate in the patients hospitalized due to a severe COVID-19 ${ }^{[20]}$.

There is not a specific anti-viral treatment for COVID-19 yet. Also, until now there is not a treatment option recommended by the evidence-based guidelines for the cytokine storm which may occur during the disease. In the beginning of the pandemic, TCZ treatment was administered in the cases with a progressed disease in the studies, but afterwards TCZ treatment was administered in the early phase of the disease. Randomized controlled clinical trials assessing the clinical efficacy with the influence of observational studies suggesting that TCZ could be effective in patients with a COVID-19 were unsatisfactory except one. In some of these studies, the sample sizes were small, and the Cls were large. In some of them, ages of the patients and comorbidities merged to be a disadvantage of the TCZ group despite the randomization. However, in the analyses of the real-world data of the cohorts, the results were promising. Results of the observational studies may include bias, or their sample size may be small. Nonetheless, we think TCZ could be an option in the selected cases because of the absence of a specific and efficient treatment for COVID-19 so far.

There are some limitations of this study. First, the patient group in the study is small. Therefore, subgroup analyses investigating the mortality related with the TCZ use in the groups with and without the comorbidities could not be performed. Second, IL-6 levels were not available in the management of the cytokine storm.

\section{Conclusion}

In conclusion, current data suggests the use of IL-6 receptor blockers to prevent the lung injury and other organ failures caused by the cytokines, although they are not recommended in the treatment in specific guidelines prepared according to the cohort and randomized controlled trials. The early and late phase treatments should be planned according to the course of the disease with well understanding the pathogenesis and the present options should be administered at the right time rationally. Our study suggests use of the TCZ in the early phase of the disease. We believe that the TCZ treatment would improve clinical response and survival and decrease the length of the hospital stay. We conclude that the randomized controlled trials including patients with different severity in any clinical phase 
of the disease in the groups having known risk factors and foreseen undergoing a severe form of the disease are needed.

\section{Ethics}

Ethics Committee Approval: The study were approved by the Bezmialem Vakıf University of Clinical Research Ethics Committee (no: 71306642-050.05.04, date: 06.05.2020).

Informed Consent: Retrospective observational cohort study.

Peer-review: Externally peer-reviewed.

\section{Authorship Contributions}

Surgical and Medical Practices: S.B., D.K., G.O., Y.A., B.D., Concept: S.B., M.M.K., T.A., Design: S.B., T.A., Data Collection or Processing: S.B., D.K., G.O., Y.A., B.S., B.D., Analysis or Interpretation: S.B., Literature Search: S.B., M.M.K., Writing: S.B.

Conflict of Interest: No conflict of interest was declared by the authors.

Financial Disclosure: The authors declared that this study received no financial support.

\section{References}

1. World Health Organization (WHO). WHO Coronavirus (COVID-19) Dashboard. Last Accessed Date: 29.07.2021. Available from: https://covid19. who.int/

2. Sheppard M, Laskou F, Stapleton PP, Hadavi S, Dasgupta B. Tocilizumab (Actemra). Hum Vaccin Immunother. 2017;13:1972-88.

3. Xu X, Han $M$, Li T, Sun W, Wang D, Fu B, Zhou Y, Zheng X, Yang Y, Li X, Zhang $X$, Pan A, Wei H. Effective treatment of severe COVID-19 patients with tocilizumab. Proc Natl Acad Sci U S A. 2020;117:10970-5.

4. Sciascia $S$, Aprà $F$, Baffa $A$, Baldovino $S$, Boaro $D$, Boero $R$, Bonora $S$, Calcagno A, Cecchi I, Cinnirella $G$, Converso $M$, Cozzi $M$, Crosasso $P, D e$ laco F, Di Perri G, Eandi M, Fenoglio R, Giusti M, Imperiale D, Imperiale G, Livigni S, Manno E, Massara C, Milone V, Natale G, Navarra M, Oddone V, Osella S, Piccioni P, Radin M, Roccatello D, Rossi D. Pilot prospective open, single-arm multicentre study on off-label use of tocilizumab in patients with severe COVID-19. Clin Exp Rheumatol. 2020;38:529-32.

5. Rosas IO, Bräu N, Waters M, Go RC, Hunter BD, Bhagani S, Skiest D, Aziz MS, Cooper N, Douglas IS, Savic S, Youngstein T, Del Sorbo L, Cubillo Gracian A, De La Zerda DJ, Ustianowski A, Bao M, Dimonaco S, Graham E, Matharu B, Spotswood H, Tsai L, Malhotra A. Tocilizumab in hospitalized patients with severe Covid-19 pneumonia. N Eng J Med. 2021;384:1503-16.

6. Keske Ş, Tekin S, Sait B, İrkören P, Kapmaz M, Çimen C, Uğur S, Çelebi i, Bakır V0, Palaoğlu E, Şentürk E, Çağlayan B, Çakar N, Tabak L, Ergönül Ö. Appropriate use of tocilizumab in COVID-19 infection. Int J Infect Dis. 2020;99:338-43.

7. Rojas-Marte G, Khalid M, Mukhtar O, Hashmi AT, Waheed MA, Ehrlich S, Aslam A, Siddiqui S, Agarwal C, Malyshev Y, Henriquez-Felipe C, Sharma D, Sharma S, Chukwuka N, Rodriguez DC, Alliu S, Le J, Shani J. Outcomes in patients with severe COVID-19 disease treated with tocilizumab: a casecontrolled study. OJM. 2020;113:546-50.
8. Horby PW, Pessoa-Amorim G, Peto L, Brightling CE, Sarkar R, Thomas K, Jeebun V, Ashish A, Tully R, Chadwick D. Tocilizumab in patients admitted to hospital with COVID-19 (RECOVERY): preliminary results of a randomised, controlled, open-label, platform trial. Medrxiv. 2021. Avaliable from: https://www.medrxiv.org/content/10.1101/2021.02.11.21249258v1

9. Tomasiewicz K, Piekarska A, Stempkowska-Rejek J, Serafińska S, Gawkowska A, Parczewski M, Niscigorska-Olsen J, Lapinski TW, Zarebska-Michaluk D, Kowalska JD. Tocilizumab for patients with severe COVID-19: a retrospective, multi-center study. Expert Rev Anti Infect Ther. 2021;19:93-100.

10. Klopfenstein T, Zayet S, Lohse A, Balblanc J-C, Badie J, Royer P-Y, Toko L, Mezher C, Kadiane-Oussou N, Bossert M. Tocilizumab therapy reduced intensive care unit admissions and/or mortality in COVID-19 patients. Med Mal Infect. 2020;50:397-400.

11. Luo P, Liu Y, Qiu L, Liu X, Liu D, Li J. Tocilizumab treatment in COVID-19: A single center experience. J Med Virol. 2020;1-5.

12. Toniati $P$, Piva $S$, Cattalini $M$, Garrafa $E$, Regola $F$, Castelli $F$, Franceschini $F$, Airò $\mathrm{P}$, Bazzani $\mathrm{C}$, Beindorf E-A. Tocilizumab for the treatment of severe COVID-19 pneumonia with hyperinflammatory syndrome and acute respiratory failure: a single center study of 100 patients in Brescia, Italy. Autoimmun Rev. 2020;19:102568.

13. Knorr JP, Colomy V, Mauriello CM, Ha S. Tocilizumab in patients with severe COVID-19: a single-center observational analysis. J Med Virol. 2020;92:2813-20.

14. Guaraldi G, Meschiari M, Cozzi-Lepri A, Milic J, Tonelli R, Menozzi M, Franceschini E, Cuomo G, Orlando G, Borghi V. Tocilizumab in patients with severe COVID-19: a retrospective cohort study. Lancet Rheumatol. 2020;2:e474-84.

15. Gupta S, Wang W, Hayek SS, Chan L, Mathews KS, Melamed ML, Brenner SK, Leonberg-Yoo A, Schenck EJ, Radbel J. Association between early treatment with tocilizumab and mortality among critically ill patients with COVID-19. JAMA Intern Med. 2021;181:41-51.

16. Sinha $P$, Mostaghim $A$, Bielick CG, McLaughlin $A$, Hamer DH, Wetzler LM, Bhadelia N, Fagan MA, Linas BP, Assoumou SA. Early administration of interleukin-6 inhibitors for patients with severe COVID-19 disease is associated with decreased intubation, reduced mortality, and increased discharge. Int J Infect Dis. 2020;99:28-33.

17. Salama C, Han J, Yau L, Reiss WG, Kramer B, Neidhart JD, Criner GJ, KaplanLewis E, Baden R, Pandit L, Cameron ML, Garcia-Diaz J, Chávez V, MekebebReuter M, Lima de Menezes F, Shah R, González-Lara MF, Assman B, Freedman J, Mohan SV. Tocilizumab in patients hospitalized with Covid-19 pneumonia. N Eng J Med. 2020;384:20-30.

18. Salvarani C, Dolci G, Massari M, Merlo DF, Cavuto S, Savoldi L, Bruzzi $P$, Boni $F$, Braglia L, Turrà $C$. Effect of tocilizumab vs standard care on clinical worsening in patients hospitalized with COVID-19 pneumonia: a randomized clinical trial. JAMA Intern Med. 2021;181:24-31.

19. Hermine 0 , Mariette $X$, Tharaux $P-L$, Resche-Rigon $M$, Porcher $R$, Ravaud $P$, Bureau $S$, Dougados M, Tibi A, Azoulay E. Effect of tocilizumab vs usual care in adults hospitalized with COVID-19 and moderate or severe pneumonia: a randomized clinical trial. JAMA Intern Med. 2021;181:32-40.

20. Abani O, Abbas A, Abbas F, Abbas M, Abbasi S, Abbass H, Abbott A, Abdallah $\mathrm{N}$, Abdelaziz $\mathrm{A}$, Abdelfattah $\mathrm{M}$. Tocilizumab in patients admitted to hospital with COVID-19 (RECOVERY): a randomised, controlled, open-label, platform trial. Lancet. 2021;397:1637-45. 